\title{
Helicobacter pylori infection and gastric mucosal epithelial cell apoptosis
}

\author{
D. Olivares, J. P. Gisbert and J. M. Pajares \\ Service of Digestive Diseases. Hospital Universitario de La Princesa. Madrid, Spain
}

Olivares D, Gisbert JP, Pajares JM. Helicobacter pylori infection and gastric mucosal epithelial cell apoptosis. Rev Esp Enferm Dig 2005; 97: 505-520. ically-managed cell death program that may be interrupted by mutations. In fact, mutations in apoptotic routes contribute to a number of human diseases ranging from neurodegenerative disorders to tumors (4).

\section{Other types of cell death}

While apoptosis is a programmed cell death, not all programmed deaths are apoptotic. Other programmed responses contribute to clear potential cancer cells. The sequence is an irreversible cell cycle arrest program with distinct characteristics that appears to be interrupted in some tumors. Selected stimuli may induce phenotypes suggesting senescence, including mitogenic oncogene activation or ionizing radiation (5-8). For instance, an excessive shortening of terminal DNA sequences or telomeres, which may naturally occur in any replication cycle, would result in chromosomal instability, thus activating a cell cycle arrest to prevent potential mutations (9) and then leading to a common program for cell death.

In contrast to apoptosis, where cells play an active role in their own destruction, in necrosis cells undergo lysis by cytokines produced by inflammatory cells. When nuclear remnants from cells having undergone necrosis are studied by electrophoresis, a diffuse pattern may be seen, since DNA fragments are in a continuous spectrum. However, nuclear remnants from cells having undergone apoptosis exhibit an alternating band pattern -in the shape of ladder rungs- known as the ladder pattern that is an unmistakable sign that the death process studied was apoptotic in nature.

\section{$H$. pylori and apoptosis}

Aceptado: 08-09-04.

Correspondencia: Javier P. Gisbert. Playa de Mojácar, 29. Urb. Bonanza. 28669 Boadilla del Monte. Madrid. e-mail: gisbert@meditex.es
On the other hand, gastric mucosal infection by Helicobacter pylori may affect the normal balance between 
gastric epithelial proliferation and death from apoptosis, thus disregulating the normal cell cycle and initially leading to gastritis. The latter may become gastric atrophy, and then subsequently metaplasia, dysplasia and gastric cancer (10). The outcome of this process correlates with a severe reduction of the apoptotic rate in early stages (gastritis and atrophy), and with a disproportionate proliferative response in the host in more advanced stages (metaplasia and dysplasia), which may ultimately end in a malignant condition. Therefore, a definition of predictive values for genetic and biochemical markers just prior to H. pylori eradication and the long-term follow-up of patients with gastric paraneoplastic lesions may help establish preventive therapeutic options.

\section{Objective}

The aim of this paper is to review the major events involved in apoptosis, their causes at both the molecular and cellular level, and their pathologic consequences, focusing on $H$. pylori-induced apoptosis in gastric mucosal epithelial cells as well as on bacterial strains.

\section{GENES INVOLVED IN APOPTOSIS}

The clonation and characterization of oncogene $b c l-2$ established the importance of apoptosis in tumor development (11). Bcl-2 promotes cell survival by blocking programmed cell death (12-14). In transgenic mice, Bcl-2 overexpression promotes lymphoproliferation and accelerates c-Myc-induced lymphomagenesis $(13,15)$. Together with Bcl-2, Bcl- $\mathrm{X}_{\mathrm{L}}$ is a potent suppressor of cell death overexpressed in a number of tumor types (16). Immune reactivity rates for $\mathrm{Bcl}-2$ in normal glands, metaplasia, adenoma, and adenocarcinoma have been seen to be 0 , 77,38 , and $11 \%$, respectively, which suggests Bcl-2 overexpression in premalignant lesions and $\mathrm{Bcl}-2$ repression following malignant conversion, this being responsible for early events in the cancer sequence (17).

Otherwise, p53 was the first tumor suppressor gene ever described in association with apoptosis. Most human tumors exhibit mutations in the $p 53$ gene, thus increasing chromosome viability and instability (18). The disruption of several protein p53 effectors (e.g. bax, apaf-1, and casp-9) may promote oncogenic transformation and tumor development (19-21). Mutated protein p53 has been seen to activate promoters for the following genes: Multi Drug Resistance Gene-1 (MDR-1), c-myc, interleukin-6 (IL-6), epithelial growth factor (EGF), and insuline-like growth factor-II (IGF-II), all of them associated with increased cell proliferation. In addition, several prior and subsequent components of the p53 pathway (e.g. Mdm-2, ARF, Bax) are also commonly mutated in human tumors (18).

Wild protein p53 is also directly or indirectly involved in the regulation of genes associated with growth factors, in the regulation of cytoskeleton-forming proteins, in the regulation of genes involved in cell adhesion, in cell cycle arrest, in the repression of cell metabolism genes, and in the maintenance of chromosome integrity following DNA damage (22). Studies in p53-defective mice have demonstrated that endogenous protein p53 may play a role in apoptosis. It was also seen that p53 was necessary for radiation-induced cell death in the thymus, but not for glycocorticoid-induced cell death $(23,24)$. Thus, the role of protein p53 in apoptosis is indirectly linked to DNA damage, and is dependant upon the stimulus (radiation) and tissue (thymocytes). Stimuli capable of p53 activation to promote apoptosis include hypoxia and mitogenic oncogenes. Should mutations occur in some of the genes associated with cancer, they may suppress apoptosis. For example, a malfunction in the Fas/CD95 pathway, which controls the number of cells in the immune system by clearing them through apoptosis, may lead to lymphoproliferative disorders and even cancer (25).

Another critical pathway implies signaling through phosphoinositol-3 (PI-3) kinase, which is activated by Ras and repressed by PTEN, a tumor suppressor. Ras activation and PTEN loss are both usual in human tumors (26).

A variety of signals may trigger apoptosis. Extracellular triggers include growth factor depletion, hypoxia, radiation, and lost cell-matrix interaction. Intracellular mechanisms include DNA damage from defective cell cycle checkpoints, endogenous toxins, telomerase (enzyme in charge of telomere replication) malfunction, and inappropriate proliferation signaling because of oncogenic mutations (27). In some cases an apoptotic signal counteracts an antiapoptotic signal. For instance, IGF-I promotes cell survival through the PI-3 kinase pathway, and IGF-I or other growth factor depletion may trigger a "depletional death" (28). In contrast, other stimuli imply true proapoptotic factors -for example, some forms of cell stress may activate protein $\mathrm{p} 53$, which promotes apoptosis through molecules such as Bax, a proapoptotic protein belonging in the Bcl-2 class $(20,21,29)$.

\section{APOPTOSIS MECHANISMS}

Better known apoptosis pathways are those starting at "death receptors" such as Fas/CD95 or TNFR1 and 2. The binding of TNF- $\alpha$ to TNFR1 results in a recruitment of TRADD (TNFR death domain) messenger molecules through interactions between proteins known as intracellular "death domains" (DD). If TRADD recruits a receptor interacting protein (RIP) and TNFR-associated factor 2 (TRAF2), the activation of nuclear factor $\kappa \mathrm{B}(\mathrm{NF}-\kappa \mathrm{B})$ ensues, which suppresses apoptosis as induced by TNF- $\alpha$ (30). In contrast, the recruitment of FADD (Fas-associated death domain) by Fas or by TNFR1 (in the latter case also through TRADD) results in apoptosis through the activation of the protease caspase 8 , thus initiating a pro- 
tease cascade leading to apoptosis (31). Caspases are cysteine proteases that are expressed as inactive proenzymes; these associate with effectors allowing their activation, and their action is to selectively cleave proteins by an aspartate residue $(32,33)$.

Some cytokines or DNA damage are signals for cell death through mitochondria. This pathway is a target for a number of oncogenic mutations affecting the function of members in the Bcl-2 family. These may modulate mitochondrial function through transition pores (MTP), whose TNF-induced aperture leads to a sharp increase in mitochondrial membrane $\mathrm{Ca}^{2+}$ permeability, which releases cytochrome c (34). Cytosolic cytochrome c may interact with apoptotic protease activation factor (Apaf-1) and procaspase 9 to initiate a protease cascade leading to apoptosis (35-37).

Selected messenger molecules alter the frequency of apoptosis induction by proapoptotic signals. For instance, cytokines such as IL-6 may suppress p53-induced apoptosis (38).

On the other hand, the PI-3 kinase pathway is involved in cell survival via extracellular cytokine receptors, which activate a kinase cascade involving PI-3 kinase and leading to the phosphorylation and inactivation of proapoptotic molecules such as Bad (another member in the Bcl-2 family) and caspase $9(39,40)$. In contrast, PTEN, which acts as a lipid phosphatase, inactivates triphosphoinositols, thus repressing this pathway $(41,42)$. In all, the previously reviewed mechanisms indicate, as summarized in figure 1, that apoptosis is a phenomenon resulting from an integration of several pro- and antiapoptotic signals that either increase or decrease the expression of specific genes.

\section{A LINK BETWEEN H. PYLORI, APOPTOSIS, AND CELL PROLIFERATION}

H. pylori is the main cause of chronic gastritis and peptic ulcer, and has been categorized as a type-I carcinogen based on seroepidemiologic evidence (43-46). H. pylori colonizes the gastric mucosa by adhering to the epithelial tissue without ever penetrating epithelial cells (47-49). H. pylori has been seen to induce apoptosis in patients with gastroduodenal ulcer and gastritis (50-55). Some authors have seen greater than five-fold increases in the number of apoptotic cells in patients with duodenal ulcer versus those observed following $H$. pylori eradication (56). In vitro studies have shown that apoptosis is induced in tumor cell lines incubated with $H$. pylori (57), as is a cell cycle arrest between phases G1 and S (58).

Both apoptosis and cell proliferation are increased in precancer lesions (atrophy, metaplasia, dysplasia) in the presence of $H$. pylori infection (59). A disregulation of genes controlling apoptosis and hence homeostasis between apoptosis and cell proliferation may ultimately lead to tumor development (60).
The gastric mucosal degeneration process is initiated by inflammation, and results in a destruction (atrophy) of gastric glands, their replacement by an intestinal-like epithelium (intestinal metaplasia), and progression to dysplasia (the earliest manifestation of a neoplasm that may be seen under a microscope) (61).

If the $H$. pylori-infected mucosa is invaded by an inflammatory cell infiltrate, glands become separated and compressed, and may falsely resemble atrophy (61). Of course, when glands are destroyed and then substituted for by another tissue (metaplastic epithelium or fibroblasts plus cell matrix), and they actually disappear (true atrophy), pathophysiological consequences are similar, and acid production decreases thus resulting in hypochlorhydria. Only atrophy characterized by intestinal metaplasia and fibrosis, and hence by a true loss of glands has been associated with the development of gastric cancer; cases of apparent atrophy may even show gland regeneration and a functional recovery of acid production (61).

Other authors reported that in premalignant lesions or gastric carcinoma increased cell proliferation is no longer associated with $H$. pylori from a certain point in time on, since eradication induces no reversal $(51,62)$, which suggests a potential association with a disregulated cell growth due to genetic changes during intestinal metaplasia, including an activation of proto-oncogenes such as $k$-ras, expression and release of gastrin and other cell growth factors, and suppression of suppressor genes such as p53 $(63,64)$. These mitogenic peptides, including the epithelial growth factor (EGF), hepatocyte growth factor (HGF, responsible for both epithelial and non-epithelial tumors), and transforming growth factor $\alpha$ (TGF- $\alpha$ ), are synthesized in the gastric mucosa, especially following H. pylori-induced damage, interact with surface receptors on epithelial cells, and induce the expression of oncogenes $c$-myc, $c$-jun and $c$-fos, which stimulate cell growth (65). A mutated k-ras causes an overexpression of mutated p53 protein followed by a phosphorylation and activation of MAP-kinases, thus enhancing tumor growth.

Gastrin, which is mainly synthesized by $\mathrm{G}$ cells at the gastric mucosa, is another factor involved in $H$. pylori-related carcinogenesis. Upon secretion to the gastric lumen in response to these bacteria, this hormone may stimulate $H$. pylori growth and $\mathrm{G}$ cells to release further gastrin, thus blocking the expression of gene $p 21$ (66) -regulated by $\mathrm{p} 53$ and involved in cell cycle arrest and apoptosisand overexpressing the mutated p53 protein (62). $H$. pylori eradication before surgery in patients with gastric cancer is followed by a sharp drop in plasma gastrin, luminal gastrin, and cancer tissue gastrin levels (67).

The Fas/Fas-ligand system is involved in apoptosis as induced by $H$. pylori in epithelial cells and lamina propria cells $(57,68-70)$. In a study the expression of FasL mRNA was higher in T-cells of infected patients versus healthy subjects, which suggests that local T-cells may induce apoptosis through Fas/FasL (71). In addition, the 


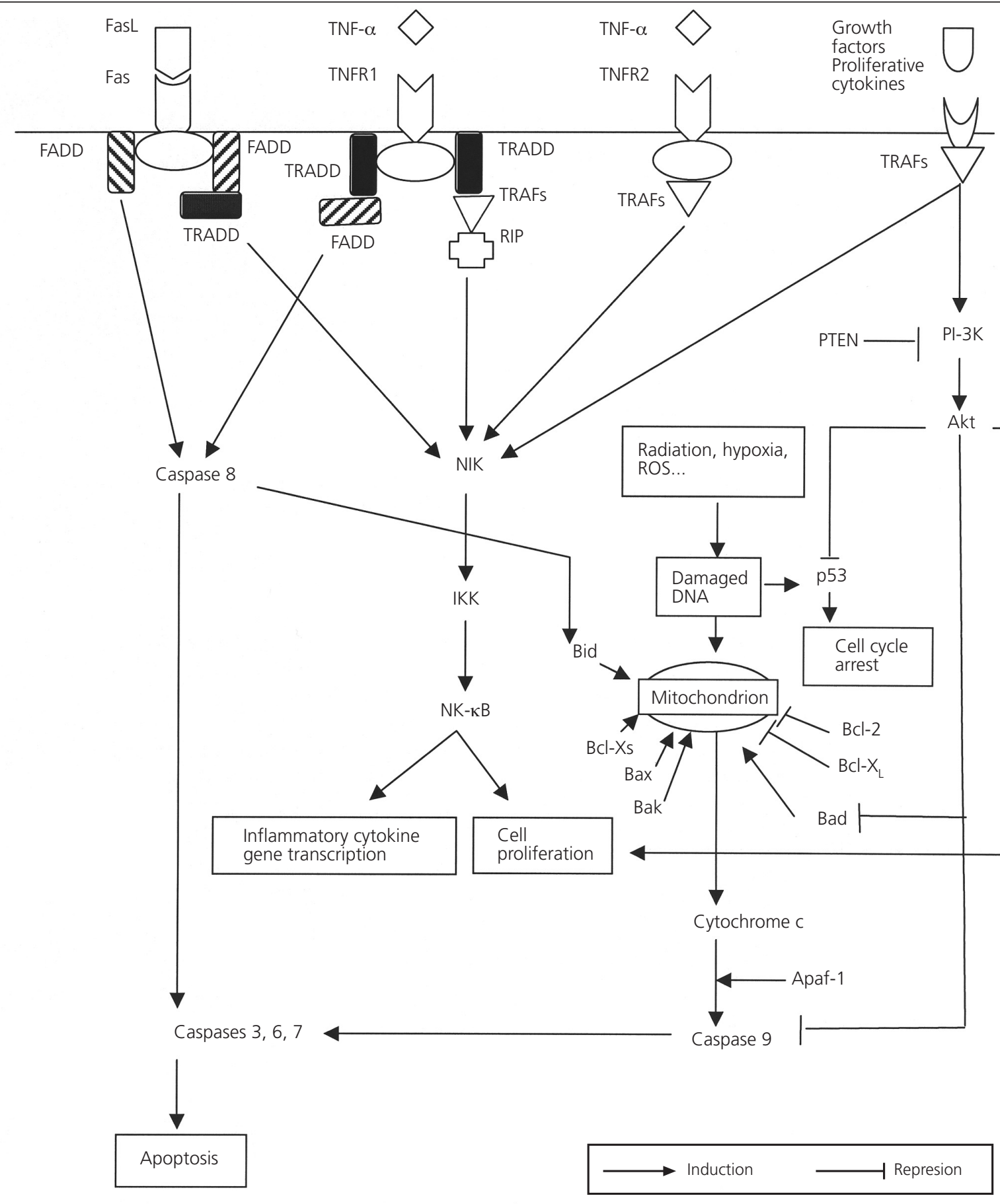

Fig. 1.- Apoptosis-related transduction routes as mediated by TNFR, Fas, or mitochondria. Receptor-mediated death and mitochondria-mediated routes are two major apoptotic routes. Receptor activation results in the recruitment of adaptor proteins. The recruitment of the Fas-associated death domain (FADD) by Fas or the tumor necrosis factor receptor (TNFR) via the TNFR-associated death domain (TRADD) activates caspase 8. Another apoptotic route begins in mitochondria. Cytochrome $\mathrm{c}$ is released into the cytosol and activates caspase 9 . The activation of caspase 8 or caspase 9 results in the activation of the caspase cascade. The nuclear factor $\kappa B$ (NF- $\kappa B$ ) route is also initiated via TRADD and TNFR-associated factors (TRAFs). NIK: NF- $\mathrm{kB}$-inducing kinase; IKK: IкB kinase- $\alpha$ and IкB kinase- $\beta$; ROS: reactive oxygen species.

Las rutas de transducción de la apoptosis mediadas por TNFR, Fas, o la mitocondria. La muerte mediada por receptores y las rutas mediadas por las mitocondrias son las dos principales rutas apoptóticas. La activación de los receptores resulta en el reclutamiento de proteínas adaptadoras. El reclutamiento del Fas associated death domain (FADD) por Fas o por el receptor del Factor de Necrosis Tumoral (TNFR) a través del TNFR associated death domain (TRADD) activan la caspasa-8. Otra ruta apoptótica comienza se inicia en la mitocondria. El citocromo-c es liberado al citosol y activa a la caspasa-9. La activación de la caspasa-8 o de la caspasa-9 conduce a la activación de la cascada de caspasas. La ruta del factor nuclear $\kappa B$ (NF- $\kappa B$ ) tam-

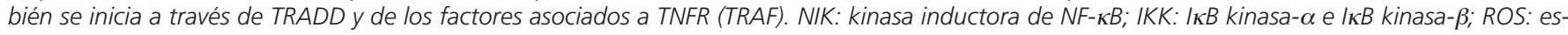
pecias reactivas de oxígeno. 
expression of FasL mRNA is also increased in gastric epithelial cells during $H$. pylori infection, which suggests that apoptosis may also be induced by epithelial cells themselves in addition to T-cell FasL, thus bringing about their own death and that of neighboring epithelial cells (69). An interaction of $H$. pylori with the main histocompatibility complex II (MHC II) as an apoptosis induction receptor in gastric epithelial cells has also been seen (72).

\section{Oxidative damage by $H$. pylori and apoptosis}

Oxygen radicals (superoxide ion and hydrogen peroxide) derived from $H$. pylori-activated neutrophils are factors that may damage the gastric mucosa (73-78). A positive association between reactive oxygen species (ROS) production and $H$. pylori-related infection and histologic damage has been described (79). Cell protection against ROS results from the activation of ROS-sequestering enzymes, including superoxide dismutase (SOD), catalase, and glutathione peroxidase.

Some authors, using the AGS epithelial cell line, found that when exposed to ROS in the absence of $H$. pylori, cell survival was reduced by $84 \%$. On the other hand, if such cells were exposed to ROS after incubation with $H$. pylori, survival was reduced to 73 and $39 \%$ for $\mathrm{cag}^{+}$and $c a g A^{-}$strains, respectively. SOD activity was also measured, and was seen to be higher in cells incubated with $\operatorname{cag} A+$ strains versus $c a g A^{-}$strains, but only the expression of the cytokine-induced Mn-SOD was increased, with a modest increase in the constitutive $\mathrm{CuZn}$ SOD. Similarly, higher levels of catalase and glutathione peroxidase activity have been reported for $c a g A^{+}$strains. This increased activity of enzymes suppressing potential DNA-damaging agents following exposure to $c a g A^{+}$ strains is probably a cause of increased cell survival following exposure to ROS (80).

Using 8-hydroxyguanidine as an oxidative damage marker in the DNA of gastric mucosal cells, H. pyloripositive patients would exhibit a higher presence of hydroxylated guanine in their DNA versus subjects with no $H$. pylori infection (81). This indicates that the damage induced in DNA by $H$. pylori infection in early gastritis may bring about its transformation into gastric cancer (80).

On the other hand, chloramine $\left(\mathrm{NH}_{3} \mathrm{Cl}\right)$ is a toxic oxidizing agent produced within the gastric mucosa by $H$. pylori invasion. In neutrophils, the enzyme myeloperoxidase catalyzes chloride oxidation by $\mathrm{H}_{2} \mathrm{O}_{2}$ into $\mathrm{HClO}$. The latter reacts with the $\mathrm{NH}_{4}^{+}$resulting from $H$. pylori metabolism and becomes $\mathrm{NH}_{3} \mathrm{Cl}$ (82), which is highly toxic due to its lipophilic and low molecular weight characteristics -it may easily cross the cell plasma membrane. In vitro studies have shown that apoptotic rates and chromatin condensation levels increase significantly more following treatment of gastric cells with $\mathrm{NH}_{3} \mathrm{Cl}$ versus $\mathrm{NH}_{4}^{+}$or $\mathrm{HClO}(83)$.
MTP and caspase 3 activation has been witnessed in cells exposed to $\mathrm{NH}_{3} \mathrm{Cl}$; these release cytochrome c (84), which forms a complex with Apaf-1 and procaspase 9, activates the latter, and initiates the caspase cascade -including caspases 3, 6 and 7- thus giving rise to the apoptotic process. In addition to $\mathrm{NH}_{3} \mathrm{Cl}$, other molecules produced by $H$. pylori, including cytotoxin VacA (85) or lipopolisaccharide, may induce apoptosis (86).

\section{Cytokines released in response to $H$. pylori infection and its related inflammatory response}

The host's $H$. pylori-stimulated inflammatory/immune response leads to a release of cytokines by Th1 cells, including TNF- $\alpha$, interferon $\gamma$ (INF- $\gamma$ ) or IL-2, which enhance apoptosis $(57,69,72)$. This response is mediated by the Fas system (87), results in caspase 3 and 8 activation following DNA fragmentation, and increases MHC II expression and binding to $H$. pylori (88). In contrast, cytokines produced by Th2 cells, including IL-10, prevent apoptosis (89).

\section{Regulation of the IL-8 gene}

IL-8 is a lymphocyte- and neutrophil-activating chemotactic cytokine secreted by gastrointestinal epithelial cells in response to bacterial infection (90) that establishes a chemotactic gradient towards the epithelium surface.

The human $\mathrm{I} L-8$ gene has several binding sites within its promoter -one for NF- $\mathrm{NB}$ and two nearby loci for the binding of proteins c-Fos and c-Jun, which together make up transcription factor $\mathrm{AP}-1$. NF- $\kappa \mathrm{B}$ is a cytoplasmic transcription factor, the activation and regulation thereof being closely regulated by a protein family designated $\mathrm{I} \kappa \mathrm{B}$-to be found non-covalently bound to NF- $\kappa \mathrm{B}-$ that prevents its translocation to the nucleus. Through signaling molecules such as TNF- $\alpha$ there is a pathway leading to I $\kappa \mathrm{B} \alpha$ and I $\kappa \mathrm{B} \beta$ phosphorylation, and I $\kappa \mathrm{B} \alpha$ proteosomal degradation; this releases $\mathrm{NF}-\kappa \mathrm{B}$, which migrates to the nucleus where it regulates the expression of a number of genes, including those involved in inflammation and cell survival (91). Two inducible kinases, IкB kinase- $\alpha$ and IкB kinase- $\beta$ (IKK- $\alpha$ and IKK- $\beta$ ), phosphorylate I $\mathrm{B} \alpha$ in response to proinflammatory cytokines (92), which are in turn phosphorylated and activated by the $\mathrm{NF}-\kappa \mathrm{B}$-inducing kinase (NIK), itself activated through proteins associated with TNF- $\alpha$ and IL- 1 receptors (93), TRAF2 and TRAF6, respectively. Since NF-кB stimulation requires no protein synthesis, it allows effective action on target genes, including $I L-8$ (91).

$\mathrm{NF}-\kappa \mathrm{B}$ activation is followed by an increased expression of mRNA and IL-8 protein $(94,95)$. The ability of $H$. pylori to activate $\mathrm{NF}-\kappa \mathrm{B}$ in vitro has been corroborated in vivo, since activated $\mathrm{NF}-\kappa \mathrm{B}$ is present in epithelial cells 
from infected patients (95). Mitogen-activated protein kinases (MAPK) are mediators in the $H$. pylori-dependant

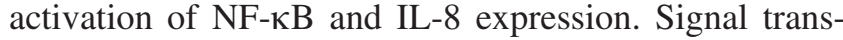
duction takes place down a cascade of MAPK kinase phosphorylations: extracellular signal-regulated kinase 1 and 2 (ERK1/2), p38, and c-Jun aminoterminal kinase (JNK). Since MAPKs activate both NF-кB and AP-1, and the $I L-8$ gene has binding domains for both, NF- $\kappa \mathrm{B}$ activation has been researched and seen to be inadequate for IL-8 expression, with the implication of AP-1 being required (96).

ERK activation by a MAPK kinase (MEKK1) leads to Elk-1 phosphorylation, which together with JNK allows $c$-fos and $c$-jun transcription, their products making up AP-1. MEKK1 and NIK may each seemingly activate

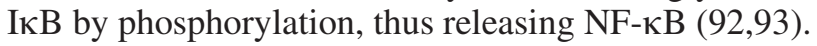

\section{Relationship between $\boldsymbol{H}$. pylori genotype and pathogenicity}

H. pylori $\mathrm{cagA}^{+}$strains induce high levels of inflammation and more severe gastritis when compared to $\mathrm{cagA}^{-}$strains, in addition to a higher risk of gastric cancer or peptic ulcer, and greater cell proliferation $(56,91,97)$. $\mathrm{CagA}^{+}$strains have been seen to notably increase IL-8 expression, hence inducing a more profound inflammatory response versus $\mathrm{cag}^{-}$strains (91). The exposure of cell cultures to $\operatorname{cag} A^{+}$strains has been seen to result in an initial increase - followed by a decrease- of p53 and p21 protein expression, whereas $\mathrm{cagA}^{-}$strains stimulate a continuous increase (98). In addition, the expression of Bcl-2 is increased in cells exposed to $\mathrm{cag}^{+}$strains, and diminished in $\mathrm{cag}^{-}$strains (98). Therefore, apoptosis seems to initially increase and subsequently decrease in $\operatorname{cag}^{+}$strains, with a persistent increase in cell proliferation. In this regard $c a g A^{-}$strains have been suggested to induce mainly apoptosis, whereas proliferation would correlate to $\mathrm{cag} A^{+}$strains (56).

However, other authors disagree with such observations, and state that both strains induce apoptosis with no differences between them $(58,99,100)$. Some authors have investigated $H$. pylori cag $\mathrm{A}^{+}$-induced apoptosis in cell cultures, and found an increased expression of Bax, a pro-apoptotic protein in the Bcl-2 family, and a suppressed expression of anti-apoptotic Bcl-2's (101).

On the other hand, H. pylori has been seen to possess a type IV secretion system, which may translocate a bacterial factor within epithelial cells that activates $\mathrm{NF}-\kappa \mathrm{B}$ and/or MAP-kinases, this resulting in IL-8 induction (91). A phosphorylation of protein CagA has been demonstrated in epithelial cells following contact with $H$. pylori $(79,102,103)$. Recent data indicate that phosphorylated CagA induces changes in the cytoskeleton, including a polymerization of actin filaments $(91,104)$.

However, $\operatorname{cagA}$ disruption does not affect NF-кB, MAP-kinase or IL-8 activation $(94,105,106)$, thus sug- gesting the presence of a different factor injected into the host cell.

\section{Changes in the expression of enzymes related to inflammation as caused by $\boldsymbol{H}$. pylori infection}

Cyclooxygenases (COX) catalyze the conversion of arachidonic acid into prostanoids such as prostaglandin $\mathrm{E}_{2}\left(\mathrm{PGE}_{2}\right)$, which protect the gastric mucosa against apoptosis, thus increasing cell proliferation $(107,108)$. Two isoenzymes exist: COX-1 and COX-2, the first one being constitutive and the second one inducible in case of lesion (107-110).

Non-steroidal anti-inflammatory drugs (NSAIDs) are amongst the most widely used drugs worldwide. Classic or nonspecific NSAIDs inhibit both COX isoforms, and their benefits are to a greater or lesser extent associated with lesions induced in the gastrointestinal tract (111).

On the other hand, the relationship between NSAIDs and $H$. pylori infection has not been elucidated, and a synergic association, antagonic association, or absolute independence on the gastroduodenal mucosa have all been postulated (112).

Gastrointestinal tract cells, including macrophages, neutrophils, myofibroblasts and endothelial cells, have been shown to express COX-2 in inflammation (107,113115). Specifically, H. pylori-related gastritis has been seen to induce its expression depending upon bacterial strain (113,115-123), which may partly explain its distinct pathogenic potential $(123,124)$. Infection by $H$. pylori $\mathrm{cag}^{+}$strains has been seen to overexpress COX-2 in patients with gastric cancer (123). In addition, some studies have demonstrated that organism eradication is associated with a decrease in COX-2 gastric expression $(116,121,125)$.

Another molecule -nitric oxide (NO)- has been seen to play a role in the protection of the gastric mucosa by increasing blood flow and inhibiting leukocyte adhesion to the endothelium (126). The normal gastric mucosa contains no inducible NO synthase (iNOS) enzyme, but its expression increases in patients with $H$. pylori-related gastritis (116).

Both iNOS and COX-2 are induced by cytokines such as IL- $1 \beta$, TNF- $\beta$ or INF- $\gamma$, phorbol esters and growth factors in general, as well as bacterial polysaccharides (127129). The induction of IL- $1 \beta$ by bacterial products has been seen to stimulate PG synthesis in a number of tissues (130), while increased PGs have also been witnessed in subjects with no clinical signs of infection (131). Cells treated with IL-1 $\beta$ have been shown to exhibit a decline and subsequent recovery of the $\mathrm{NF}-\kappa \mathrm{B}$ inhibitor protein I $\mathrm{B} \alpha$, which suggests that treatment with IL- $1 \beta$ activates NF-кB (132).

On the other hand, the effect of mutated p53 on COX2 expression and $\mathrm{PGE}_{2}$ production has been investigated 
using in vitro experiments, and cells with wild-type p53 were found to produce $90 \%$ less $\mathrm{PGE}_{2}$ than cells with mutated p53, and to completely suppress COX-2 expression (133). Wild-type p53 also blocks the induction of $C O X-2$ promoter activity by phorbol esters (133).

It is important to note that NO is mutagenic $(134,135)$, and its metabolites, including nitrosamines, are involved in gastric carcinogenesis (136). COX-2 products have also been shown to be both mutagenic (137) y carcinogenic $(138,139)$. Several binding sites for transcription factors have been identified within the COX-2 gene promoter, including two for $\mathrm{NF}-\kappa \mathrm{B}$ that regulate $\mathrm{COX}-2$ transcription (132).

The extent of expression for both genes has been seen to be higher in tissues from patients with gastritis and concomitant $H$. pylori infection than in tissues of patients with gastritis and no $H$. pylori infection, whereas the level of constitutive cyclooxygenase COX-1 was approximately identical in all tissues (116). Consistent with the fact that $H$. pylori colonization is greater in the antrum versus the gastric body $(140,141)$, the extent of expression of both iNOS and $C O X-2$ has been seen to also be considerably higher in the antrum. However, it should be noted that a recent study showed inflammation levels that were not significantly higher in the antrum versus the gastric body, which suggests a direct effect of $H$. pylori on the induction of expression for both genes (116).

\section{CONCLUSIONS}

In summary, a number of conclusions may be drawn, which are discussed below:

-Apoptosis is a process of programmed cell death under genetic control that may be altered by a number of factors, including oxidative stress, ionizing radiation, hypoxia, etc.; these may ultimately lead to mutations in oncogenes regulating the apoptosis/cell proliferation process, which may throw gastric homeostasis out of balance and lead to the development of tumors.

- Another factor that may alter the balance between apoptosis and proliferation, specifically at the gastric mucosa, is $H$. pylori infection. The outcome may be a dramatically increased apoptosis rate, which may lead to gastritis or ulcer, or result in increased cell proliferation and reduced apoptosis, which may potentially progress to metaplasia, dysplasia, and eventually adenocarcinoma.

-To conclude, the relationship between $H$. pylori strain genotype and the organism's pathogenic potential remains unclear, albeit a number of papers report an association of $\operatorname{cag} A^{+}$strains with reduced apoptosis and the development of neoplastic processes on the one hand, and an association of $c a g A^{-}$strains with a higher-thannormal apoptotic rate on the other hand. In contrast, other authors draw opposite conclusions when failing to demonstrate differences in apoptotic rates between $H$. $p y$ lori $\mathrm{cagA}^{+}$and $\mathrm{cagA}^{-}$strains, or to show that cag $\mathrm{A}^{+}$strains indeed give rise to higher apoptotic rates, this being the reason why this association remains a highly controversial topic.

\section{ACKNOWLEDGEMENTS}

This review has been partly supported by a grant from Instituto de Salud Carlos III (03/02).

\section{REFERENCES}

1. Kerr JF, Wyllie AH, Currie AR. Apoptosis: a basic biological phenomenon with wide-ranging implications in tissue kinetics. $\mathrm{Br} \mathrm{J}$ Cancer 1972; 26: 239-57.

2. Kerr JF, Winterford CM, Harmon BV. Apoptosis. Its significance in cancer and cancer therapy. Cancer 1994; 73: 2013-26.

3. Fukuda T, Wang H, Nakanishi H, Yamamoto K, Kosaka T. Novel non-apoptotic morphological changes in neurons of the mouse hippocampus following transient hypoxic-ischemia. Neurosci Res 1999; 33: 49-55.

4. Thompson CB. Apoptosis in the pathogenesis and treatment of disease. Science 1995; 267: 1456-62.

5. Linke SP, Clarkin KC, Di Leonardo A, Tsou A, Wahl GM. A reversible, p53-dependent G0/G1 cell cycle arrest induced by ribonucleotide depletion in the absence of detectable DNA damage. Genes Dev 1996; 10: 934-47.

6. Lin AW, Barradas M, Stone JC, van Aelst L, Serrano M, Lowe SW. Premature senescence involving p53 and p16 is activated in response to constitutive MEK/MAPK mitogenic signaling. Genes Dev 1998; 12: 3008-19.

7. Serrano M, Lin AW, McCurrach ME, Beach D, Lowe SW. Oncogenic ras provokes premature cell senescence associated with accumulation of p53 and p16INK4a. Cell 1997; 88: 593-602.

8. Zhu J, Woods D, McMahon M, Bishop JM. Senescence of human fibroblasts induced by oncogenic Raf. Genes Dev 1998; 12: 29973007.

9. Wynford-Thomas D. Cellular senescence and cancer. J Pathol 1999; 187: 100-11.

10. Nardone G, Staibano S, Rocco A, Mezza E, D'Armiento FP, Insabato L, et al. Effect of Helicobacter pylori infection and its eradication on cell proliferation, DNA status, and oncogene expression in patients with chronic gastritis. Gut 1999; 44: 789-99.

11. Baldini L, Pretolani S, Bonvicini F, Miglio F, Epifanio G, Gentiloni Silveri N, et al. Effect of Helicobacter pylori infection, age and epithelial cell turnover in a general population at high risk for gastric cancer. Panminerva Med 1999; 41: 187-92.

12. Vaux DL, Cory S, Adams JM. Bcl-2 gene promotes haemopoietic cell survival and cooperates with c-myc to immortalize pre-B cells. Nature 1988; 335: 440-2

13. McDonnell TJ, Deane N, Platt FM, Nunez G, Jaeger U, McKearn $\mathrm{JP}$, et al. bcl-2-immunoglobulin transgenic mice demonstrate extended B cell survival and follicular lymphoproliferation. Cell 1989; 57: 79-88.

14. Hockenbery D, Nunez G, Milliman C, Schreiber RD, Korsmeyer SJ. $\mathrm{Bcl}-2$ is an inner mitochondrial membrane protein that blocks programmed cell death. Nature 1990; 348: 334-6.

15. Strasser A, Harris AW, Bath ML, Cory S. Novel primitive lymphoid tumours induced in transgenic mice by cooperation between myc and bcl-2. Nature 1990; 348: 331-3.

16. Reed JC. Bcl-2 family proteins. Oncogene 1998; 17: 3225-36.

17. Nakamura T, Nomura S, Skai T. Expression of Bcl-2 oncoprotein in gastrointestinal and uterine carcinomas and their premalignant lesions. Hum Pathol 1997; 28: 309-15.

18. Wallace-Brodeur RR, Lowe SW. Clinical implications of p53 mutations. Cell Mol Life Sci 1999; 55: 64-75. 
19. Soengas MS, Alarcon RM, Yoshida H, Giaccia AJ, Hakem R, Mak TW, et al. Apaf-1 and caspase-9 in p53-dependent apoptosis and tumor inhibition. Science 1999; 284: 156-9.

20. Yin C, Knudson CM, Korsmeyer SJ, Van Dyke T. Bax suppresses tumorigenesis and stimulates apoptosis in vivo. Nature 1997; 369: 637-40.

21. McCurrach ME, Connor TM, Knudson CM, Korsmeyer SJ, Lowe SW. bax-deficiency promotes drug resistance and oncogenic trnasformation by attenuating p53-dependent apoptosis. Proc Natl Acad Sci 1997; 94: 2345-9.

22. Sigal A, Rotter V. Oncogenic Mutations of the p53 Tumor Suppressor: The Demons of the Guardian of the Genome. Cancer Res 2000; 60: 6788-93.

23. Lowe SW, Schmitt EM, Smith SW, Osborne BA, Jacks T. p53 is required for radiation-induced apoptosis in mouse thymocytes. Nature 1993; 362: 847-9.

24. Clarke AR, Purdie CA, Harrison DJ, Morris RG, Bird CC, Hooper ML, et al. Thymocyte apoptosis induced by p53-dependent and independent pathways. Nature 1993; 362: 849-52.

25. Beltinger C, Bohler T, Schrappe M, Ludwig WD, Debatin KM. The role of CD95 (APO-1/Fas) mutations in lymphoproliferative and malignant lymphatic diseases. Klin Padiatr 1998; 210 : 153-8.

26. Cantley LC, Neel BG. New insights into tumos suppression: PTEN suppresses tumor formation by restraining the phosphoinositide 3kinase/Akt pathway. Proc Natl Acad Sci 1999; 96: 4240-5.

27. Lowe SW, Lin AW. Apoptosis in cancer. Carcinogenesis 1999; 21 : 485-95.

28. Raff MC. Social controls in cell survival and cell death. Nature 1992; 356: 397-400.

29. Miyashita T, Reed JC. Tumor suppressor p53 is a direct transcription activator of the bax human gene. Cell 1995; 80: 293-9.

30. Takeuchi M, Rothe M, Goeddel DV. Anatomy of TRAF2. Distinct domains for nuclear factor-kappaB activation and association with tumor necrosis factor signaling proteins. J Biol Chem 1996; 271: 19935-42.

31. Kuwano K, Hara N. Signal transduction pathways of apoptosis and inflammation induced by the tumor necrosis factor receptor family. Am J Respir Cell Mol Biol 2000; 22: 147-9.

32. Muzio M, Stockwell BR, Stennicke HR, Salvesen GS, Dixit VM. An induced proximity model for caspase-8 activation. J Biol Chem 1998; 273: 2926-30.

33. $\mathrm{Hu}$ Y, Benedict MA, Wu D, Inohara N, Nunez G. Bcl-XL interacts with Apaf-1 and inhibits Apaf-1-dependent caspase-9 activation. Proc Natl Acad Sci U S A 1998; 95: 4386-91.

34. Green DR, Reed JC. Mitochondria and apoptosis. Science 1998; 281: 1309-12.

35. Srinivasula SM, Ahmad M, Fernandes-Alnemri T, Alnemri ES. Autoactivation of procaspase- 9 by Apaf-1-mediated oligomerization. Mol Cell 1998; 1: 949-57.

36. Zou H, Henzel WJ, Liu X, Lutschg A, Wang X. Apaf-1, a human protein homologous to C. elegans CED-4, participates in cytochrome c-dependent activation of caspase-3. Cell 1997; 90: 40513.

37. Li P, Nijhawan D, Budihardjo I, Srinivasula SM, Ahmad M, Alnemri ES, et al. Cytochrome c and dATP-dependent formation of Apaf1/caspase- 9 complex initiates an apoptotic protease cascade. Cell 1997; 91: 479-89.

38. Yonish-Rouach E, Resnitzky D, Lotem J, Sachs L, Kimchi A, Oren M. Wild-type p53 induces apoptosis of myeloid leukaemic cells that is inhibited by interleukin-6. Nature 1991; 352: 345-7.

39. del Peso L, Gonzalez-Garcia M, Page C, Herrera R, Nunez G. Interleukin-3-induced phosphorilation of Bad through the protein kinase Akt. Science 1997; 278: 687-9.

40. Cardone MH, Roy N, Stennicke HR, Salvesen GS, Franke TF, Stanbridge $\mathrm{E}$, et al. Regulation of cell death protease caspase- 9 by phosphorilation. Science 1998; 282: 1318-21.

41. Myers MP, Pass I, Batty IH, Van der Kaay J, Stolarov JP, Hemmings BA, et al. The lipid phosphatase activity of PTEN its critica for its tumor suppression function. Proc Natl Acad Sci 1998; 95 13513-8.

42. Maehama T, Dixon JE. PTEN: a tumour suppressor that functions as a phospholipid phosphatase. Trends Cell Biol 1999; 9: 125-8.
43. NIH Consensus Conference. Helicobacter pylori in peptic ulcer disease. NIH consensus development panel. JAMA 1994; 272: 65-9.

44. Parsonnet J, Friedman GD, Vandersteen DP, Chang Y, Vogelman $\mathrm{JH}$, Orentreich N, et al. Helicobacter pylori infection and the risk of gastric carcinoma. N Engl J Med 1991; 325: 1127-31.

45. Forman D. Helicobacter pylori and gastric cancer. Scand J Gastroenterol Suppl 1996; 220: 23-6.

46. Cover TL, Krishna US, Israel DA, Peek RM, Jr. Induction of gastric epithelial cell apoptosis by Helicobacter pylori vacuolating cytotoxin. Cancer Res 2003; 63: 951-7.

47. Chen XG, Correa P, Offerhaus J, Rodriguez E, Janney F, Hoffmann $\mathrm{E}$, et al. Ultrastructure of the gastric mucosa harboring Campylobacter-like organisms. Am J Clin Pathol 1986; 86: 575-82.

48. Hessey SJ, Spencer J, Wyatt JI, Sobala G, Rathbone BJ, Axon AT, et al. Bacterial adhesion and disease activity in Helicobacter associated chronic gastritis. Gut 1990; 31: 134-8.

49. Kazi JL, Sinniah R, Zaman V, Ng ML, Jafarey NA, Alam SM, et al. Ultrastructural study of Helicobacter pylori-associated gastritis. J Pathol 1990; 161: 65-70.

50. Harvard TJ, Sarsfield P, Wotherspoon AC. Increased gastric epithelial cell proliferation in Helicobacter pylori-associated follicular gastritis. J Clin Pathol 1996; 49: 68-71.

51. Cahill RJ, Xia H, Kilgallen C, Beattie S, Hamilton H, O'Morain C. Effect of eradication of Helicobacter pylori infection on gastric epithelial cell proliferation. Dig Dis Sci 1995; 40: 1627-31.

52. Cahill RJ, Kilgallen C, Beattie S, Hamilton H, O'Morain C. Gastric epithelial cell kinetics in the progression from normal mucosa to gastric carcinoma. Gut 1996; 38: 177-81.

53. Lynch DA, Mapstone NP, Clarke AM, Sobala GM, Jackson P, Morrison L, et al. Cell proliferation in Helicobacter pylori associated gastritis and the effect of eradication therapy. Gut 1995; 36: 346-50.

54. Fraser AG, Sim R, Sankey EA, Dhillon AP, Pounder RE. Effect of eradication of Helicobacter pylori on gastric epithelial cell proliferation. Aliment Pharmacol Ther 1994; 8: 167-73.

55. Brenes F, Ruiz B, Correa P, Hunter F, Rhamakrishnan T, Fontham $\mathrm{E}$, et al. Helicobacter pylori causes hyperproliferation of the gastric epithelium: pre- and post-eradication indices of proliferating cell nuclear antigen. Am J Gastroenterol 1993; 88: 1870-5.

56. Peek RM, Jr., Moss SF, Tham KT, Perez-Perez GI, Wang S, Miller GG, et al. Helicobacter pylori cagA+ strains and dissociation of gastric epithelial cell proliferation from apoptosis. J Natl Cancer Inst 1997; 89: 863-8.

57. Wagner S, Beil W, Westermann J, Logan RP, Bock CT, Trautwein $\mathrm{C}$, et al. Regulation of gastric epithelial cell growth by Helicobacter pylori: offdence for a major role of apoptosis. Gastroenterology 1997; 113: 1836-47.

58. Shirin H, Sordillo EM, Oh SH, Yamamoto H, Delohery T, Weinstein IB, et al. Helicobacter pylori inhibits the G1 to S transition in AGS gastric epithelial cells. Cancer Res 1999; 59: $2277-$ 81.

59. Fukui H, Franceschi F, Penland RL, Sakai T, Sepulveda AR, Fujimori T, et al. Effects of Helicobacter pylori infection on the link between regenerating gene expression and serum gastrin levels in Mongolian gerbils. Lab Invest 2003; 83: 1777-86.

60. Xia HH, Talley NJ. Apoptosis in Gastric Epithelium Induced by Helycobacter pylori Infection: Implications in Gastric Carcinogenesis. Am J Gastroenterol 2001; 96: 16-26.

61. Genta RM. Helicobacter pylori, inflammation, mucosal damage, and apoptosis: pathogenesis and definition of gastric atrophy. Gastroenterology 1997; 113: S51-5.

62. Ierardi E, Francavilla A, Balzano T, Traversa A, Principi M, Monno RA, et al. Effect of Helicobacter pylori eradication on gastric epithelial proliferation. Relationship with ras oncogene p21 expression. Ital J Gastroenterol Hepatol 1997; 29: 214-9.

63. Konturek PC, Konturek SJ, Pierzchalski P, Bielanski W, Duda A Marlicz K, et al. Cancerogenesis in Helicobacter pylori infected stomach-role of growth factors, apoptosis and cyclooxygenases. Med Sci Monit 2001; 7: 1092-107.

64. Jorge O, Cuello Carrion FD, Jorge A, Ciocca DR. La infección por Helicobacter pylori afecta a la expresión de PCNA, p53, c-erbB-2 y Bcl-2 en la mucosa gástrica humana. Rev Esp Enferm Dig 2003; 95: 89-96. 
65. Cutry AF, Kinniburgh AJ, Krabak MJ, Hui SW, Wenner CE. Induction of c-fos and c-myc proto-oncogene expression by epidermal growth factor and transforming growth factor alpha is calcium-independent. J Biol Chem 1989; 264: 19700-5.

66. Konturek SJ, Konturek PC, Hartwich A, Hahn EG. Helicobacter pylori infection and gastrin and cyclooxygenase expression in gastric and colorectal malignancies. Regul Pept 2000; 93: 13-9.

67. Konturek PC, Hartwich A, Zuchowicz M, Labza H, Pierzchalski P, Karczewska E, et al. Helicobacter pylori, gastrin and cyclooxygenases in gastric cancer. J Physiol Pharmacol 2000; 51: 737-49.

68. Jones NL, Day AS, Jennings HA, Sherman PM. Helicobacter pylori induces gastric epithelial cell apoptosis in association with increased Fas receptor expression. Infect Immun 1999; 67: 4237-42.

69. Rudi J, Kuck D, Strand S, von Herbay A, Mariani SM, Krammer $\mathrm{PH}$, et al. Involvement of the CD95 (APO-1/Fas) receptor and ligand system in Helicobacter pylori-induced gastric epithelial apoptosis. J Clin Invest 1998; 102: 1506-14.

70. Wang J, Fan X, Brook EG. Gastric T cells damage the epithelium during $H$. pylori infection through interactions between Fas receptor and Fas ligand. Gastroenterology 1999; 116: A842 (abstract).

71. Fan XJ, Chua A, Shahi CN, McDevitt J, Keeling PW, Kelleher D. Gastric T lymphocyte responses to Helicobacter pylori in patients with H pylori colonisation. Gut 1994; 35: 1379-84.

72. Fan X, Crowe SE, Behar S. The Effect of Class II Major Histocompatibility Complex Expression on Adherence of Helicobacter pylor and Induction of Apoptosis in Gastric Epithelial Cells: A Mechanism for T Helper Cell Type 1-mediated Damage. J Exp Med 1998; 187: 1659-69.

73. Davies GR, Simmonds NJ, Stevens TR, Sheaff MT, Banatvala N, Laurenson IF, et al. Helicobacter pylori stimulates antral mucosal reactive oxygen metabolite production in vivo. Gut 1994; 35: 17985.

74. Suzuki H, Miura S, Suzuki M, Terada S, Nakamura M, Tsuchiya M. Gastric mucosal injury: microcirculation and Helicobacter pylori. Keio J Med 1994; 43: 1-8.

75. Suzuki H, Miura S, Imaeda H, Suzuki M, Han JY, Mori M, et al. Enhanced levels of chemiluminescence and platelet activating factor in urease-positive gastric ulcers. Free Radic Biol Med 1996; 20: 44954.

76. Suzuki H, Suzuki M, Mori M, Kitahora T, Yokoyama H, Miura S, et al. Augmented levels of gastric mucosal leucocyte activation by infection with cagA gene-positive Helicobacter pylori. J Gastroenterol Hepatol 1998; 13: 294-300.

77. Suzuki H, Mori M, Seto K, Kai A, Kawaguchi C, Suzuki M, et al. Helicobacter pylori-associated gastric pro- and antioxidant formation in Mongolian gerbils. Free Radic Biol Med 1999; 26: 679-84.

78. Suzuki H, Yanaka A, Shibahara T, Matsui H, Nakahara A, Tanaka $\mathrm{N}$, et al. Ammonia-induced apoptosis is accelerated at higher $\mathrm{pH}$ in gastric surface mucous cells. Am J Physiol Gastrointest Liver Physiol 2002; 283: G986-95.

79. Asahi M, Azuma T, Ito S, Ito Y, Suto H, Nagai Y, et al. Helicobacter pylori CagA protein can be tyrosine phosphorylated in gastric epithelial cells. J Exp Med 2000; 191: 593-602.

80. Smoot DT, Elliott TB, Verspaget HW, Jones D, Allen CR, Vernon $\mathrm{KG}$, et al. Influence of Helicobacter pylori on reactive oxygen-induced gastric epithelial cell injury. Carcinogenesis 2000; 21: 20915.

81. Baik SC, Youn HS, Chung MH, Lee WK, Cho MJ, Ko GH, et al. Increased oxidative DNA damage in Helicobacter pylori-infected human gastric mucosa. Cancer Res 1996; 56: 1279-82.

82. Suzuki H, Seto K, Mori M, Suzuki M, Miura S, Ishii H. Monochloramine induced DNA fragmentation in gastric cell line MKN45. Am J Physiol 1998; 275: G712-6.

83. Suzuki H, Mori M, Suzuki M, Sakurai K, Miura S, Ishii H. Extensive DNA damage induced by monochloramine in gastric cells. Cancer Lett 1997; 115: 243-8.

84. Suzuki H, Nagahashi S, Seto K, Mori M. Mitochondrial permeability transition and caspase-3 activation in monochloramine $(\mathrm{NH} 2 \mathrm{Cl})$ induced gastric epithelial apoptosis. Gastroenterology 1999; 116: A512 (abstract).

85. Hou P, Tu ZX, Xu GM, Gong YF, Ji XH, Li ZS. Helicobacter pylori vacA genotypes and cagA status and their relationship to associated diseases. World J Gastroenterol 2000; 6: 605-7.
86. Piotrowski J, Skrodzka D, Slomiany A, Slomiany BL. Helicobacter pylori lipopolysaccharide induces gastric epithelial cells apoptosis. Biochem Mol Biol Int 1996; 40: 597-602.

87. Houghton J, Korah RM, Condon MR, Kim KH. Apoptosis in $\mathrm{He}$ licobacter pylori-associated gastric and duodenal ulcer disease is mediated via the Fas antigen pathway. Dig Dis Sci 1999; 44: 465 78.

88. Fan X, Gunasena H, Cheng Z. Helicobacter pylori Urease Binds to Class II MHC on Gastric Epithelial Cells and Induces Their Apoptosis. J Immunol 2000; 165: 1918-24.

89. Luthra S, Fan X, Song F, Wang J. IL-10 prevents induction of apoptosis of gastric epithelial cells by $H$. pylori and interferon-gamma. Gastroenterology 1997; 116: A818 (abstract).

90. Eckmann L, Kagnoff MF, Fierer J. Epithelial cells secrete the chemokine interleukin- 8 in response to bacterial entry. Infect Immun 1993; 61: 4569-74.

91. Peek RM. Helicobacter pylori strain-specific activation of signal transduction cascades related to gastric inflammation. Am J Gastrointest Liver Physiol 2001; 280: G525-G530.

92. Mercurio F, Zhu H, Murray BW, Shevchenko A, Bennett BL, Li J, et al. IKK-1 and IKK-2: cytokine-activated IkappaB kinases essential for NF-kappaB activation. Science 1997; 278: 860-6.

93. Malinin NL, Boldin MP, Kovalenko AV, Wallach D. MAP3K-related kinase involved in NF-kappaB induction by TNF, CD95 and IL1. Nature 1997; 385: 540-4

94. Sharma SA, Tummuru MK, Blaser MJ, Kerr LD. Activation of IL-8 gene expression by Helicobacter pylori is regulated by transcription factor nuclear factor-kappa B in gastric epithelial cells. J Immunol 1998; 160: 2401-7.

95. Keates S, Hitti YS, Upton M, Kelly CP. Helicobacter pylori infection activates NF-kappa B in gastric epithelial cells. Gastroenterology 1997; 113: 1099-109.

96. Aihara M, Tsuchimoto D, Takizawa H, Azuma A, Wakebe $\mathrm{H}$ Ohmoto Y, et al. Mechanisms involved in Helicobacter pylori-induced interleukin- 8 production by a gastric cancer cell line, MKN45. Infect Immun 1997; 65: 3218-24.

97. Ashktorab H, Allen CR, Reeves B. Regulation of apoptosis by differential expression of walf1, p53 and bcl-2 in gastric cells exposed to H. pylori. Gastroenterology 1997; 112: A534 (abstract).

98. Ashktorab H, Frank S, Khaled AR, Durum SK, Kifle B, Smoot DT. Bax translocation and mitochondrial fragmentation induced by Helicobacter pylori. Gut 2004; 53: 805-13.

99. Li H, Mellgard B, Helander HF. Inoculation of VacA- and CagAHelicobacter pylori delays gastric ulcer healing in the rat. Scand J Gastroenterol 1997; 32: 439-44.

100. Li H, Kalies I, Mellgard B, Helander HF. A rat model of chronic Helicobacter pylori infection. Studies of epithelial cell turnover and gastric ulcer healing. Scand J Gastroenterol 1998; 33: 370-8.

101. Konturek PC, Pierzchalski P, Konturek SJ, Meixner H, Faller G, Kirchner T, et al. Helicobacter pylori induces apoptosis in gastric mucosa through an upregulation of Bax expression in humans. Scand J Gastroenterol 1999; 34: 375-83.

102. Stein M, Rappuoli R, Covacci A. Tyrosine phosphorylation of the Helicobacter pylori CagA antigen after cag-driven host cell translocation. Proc Natl Acad Sci U S A 2000; 97: 1263-8.

103. Odenbreit S, Puls J, Sedlmaier B, Gerland E, Fischer W, Haas R. Translocation of Helicobacter pylori CagA into gastric epithelial cells by type IV secretion. Science 2000; 287: 1497-500.

104. Segal ED, Cha J, Lo J, Falkow S, Tompkins LS. Altered states: involvement of phosphorylated CagA in the induction of host cellular growth changes by Helicobacter pylori. Proc Natl Acad Sci U S A 1999; 96: 14559-64.

105. Keates S, Keates AC, Warny M, Peek RM, Jr., Murray PG, Kelly CP. Differential activation of mitogen-activated protein kinases in AGS gastric epithelial cells by cag+ and cag-Helicobacter pylori. J Immunol 1999; 163: 5552-9.

106. Tummuru MK, Sharma SA, Blaser MJ. Helicobacter pylori picB, a homologue of the Bordetella pertussis toxin secretion protein, is required for induction of IL- 8 in gastric epithelial cells. Mol Microbiol 1995; 18 : 867-76.

107. Gisbert JP, Pajares JM. Ciclooxigenasa-2 (COX-2), Helicobacter pylori y cáncer gástrico. Med Clin (Barc) 2003; 120: 189-93. 
108. Gisbert JP, Pajares JM. Ciclooxigenasa-2 (COX-2) y lesiones gastroduodenales. ¿Alguna relación con Helicobacter pylori? Una revisión sistemática. Med Clin (Barc) 2003; 120: 550-8.

109. Lanas A, Martin-Mola E, Ponce J, Navarro F, Pique JM, Blanco FJ. Clinical strategy to prevent the gastrointestinal adverse effects of nonsteroidal anti-inflammatory agents. Gastroenterol Hepatol 2003; 26: 485-502.

110. Halter F, Tarnawski AS, Schmassmann A, Peskar BM. Cyclooxygenase 2-implications on maintenance of gastric mucosal integrity and ulcer healing: controversial issues and perspectives. Gut 2001; 49: 443-53.

111. Hawkey CJ. Non-steroidal anti-inflammatory drugs and peptic ulcers. BMJ 1990; 300: 278-84

112. Gisbert JP, Boixeda D, Martín de Argila C, García Plaza A. Lesiones gastroduodenales y antiinflamatorios no esteroideos: ¿Qué papel desempeña Helicobacter pylori en esta relación? Rev Esp Enferm Dig 1998; 90: 655-64.

113. Tatsuguchi A, Sakamoto C, Fukuda Y, Wada K, Akamatsu T, Tsukui $\mathrm{T}$, et al. Induction of cyclooxygenase- 2 in mesothelial cells in peritonitis caused by perforated ulcers-an immunohistochemical study in humans. Aliment Pharmacol Ther 2000; 14 (Supl. 1): 5863.

114. Wallace J. Distribution and expression of cyclooxygenase (COX) isoenzymes, their physiological roles, and the categorization of nonsteroidal anti-inflammatory drugs (NSAIDs). Am J Med 1999; 107: 11S-16S; discussion 16S-17S.

115. Jackson LM, Wu KC, Mahida YR, Jenkins D, Hawkey CJ. Cyclooxygenase (COX) 1 and 2 in normal, inflamed, and ulcerated human gastric mucosa. Gut 2000; 47: 762-70.

116. Fu S, Ramanujam KS, Wong A, Fantry GT, Drachenberg CB, James $\mathrm{SP}$, et al. Increased expression and cellular localization of inducible nitric oxide synthase and cyclooxygenase 2 in Helicobacter pylori gastritis. Gastroenterology 1999; 116: 1319-29.

117. Chan FK, To KF, Ng YP, Lee TL, Cheng AS, Leung WK, et al. Expression and cellular localization of COX-1 and -2 in Helicobacter pylori gastritis. Aliment Pharmacol Ther 2001; 15: 187 93.

118. Franco L, Talamini G, Carra G, Doria D. Expression of COX-1, COX-2, and inducible nitric oxide synthase protein in human gastric antrum with Helicobacter pylori infection. Prostaglandins Other Lipid Mediat 1999; 58: 9-17.

119. Kimura A, Tsuji S, Tsujii M, Sawaoka H, Iijima H, Kawai N, et al. Expression of cyclooxygenase-2 and nitrotyrosine in human gastric mucosa before and after Helicobacter pylori eradication. Prostaglandins Leukot Essent Fatty Acids 2000; 63: 315-22.

120. Zarrilli R, Tuccillo C, Santangelo M, Nardone G, Romano M. Increased COX-2, but not COX-1, mRNA expression in Helicobacter pylori gastritis. Am J Gastroenterol 1999; 94: 3376-8.

121. McCarthy CJ, Crofford LJ, Greenson J, Scheiman JM. Cyclooxygenase-2 expression in gastric antral mucosa before and after eradication of Helicobacter pylori infection. Am J Gastroenterol 1999; 94 1218-23.

122. Byrne MF, Murphy JF, Corcoran PA, Atherton JC, Sheehan KM, Cox D, et al. Helicobacter pylori induces cyclooxygenase-1 and cyclooxygenase-2 expression in vascular endothelial cells. Scand J Gastroenterol 2003; 38: 1023-30.

123. Guo XL, Wang LE, Du SY, Fan CL, Li L, Wang P, et al. Association of cyclooxygenase-2 expression with Hp-cagA infection in gastric cancer. World J Gastroenterol 2003; 9: 246-9.

124. Wilson KT, Ramanujam KS, Shirin H. Prostaglandin E inhibits
Helycobacter pylori-induced apoptosis. Gastroenterology 1998; 116: A530 (abstract).

125. Konturek PC, Rembiasz K, Konturek SJ, Stachura J, Bielanski W, Galuschka K, et al. Gene expression of ornithine decarboxylase, cyclooxygenase-2, and gastrin in atrophic gastric mucosa infected with Helicobacter pylori before and after eradication therapy. Dig Dis Sci 2003; 48: 36-46.

126. Lopez-Belmonte J, Whittle BJ, Moncada S. The actions of nitric oxide donors in the prevention or induction of injury to the rat gastric mucosa. Br J Pharmacol 1993; 108: 73-8.

127. Xie QW, Cho HJ, Calaycay J, Mumford RA, Swiderek KM, Lee $\mathrm{TD}$, et al. Cloning and characterization of inducible nitric oxide synthase from mouse macrophages. Science 1992; 256: 225-8.

128. Lowenstein CJ, Glatt CS, Bredt DS, Snyder SH. Cloned and expressed macrophage nitric oxide synthase contrasts with the brain enzyme. Proc Natl Acad Sci U S A 1992; 89: 6711-5.

129. Arias-Negrete S, Keller K, Chadee K. Proinflammatory cytokines regulate cyclooxygenase- 2 mRNA expression in human macrophages. Biochem Biophys Res Commun 1995; 208: 582-9.

130. Mitchell MD, Romero RJ, Avila C, Foster JT, Edwin SS. Prostaglandin production by amnion and decidual cells in response to bacterial products. Prostaglandins Leukot Essent Fatty Acids 1991; 42: 167-9.

131. Romero R, Parvizi ST, Oyarzun E, Mazor M, Wu YK, Avila C, et al. Amniotic fluid interleukin-1 in spontaneous labor at term. J Reprod Med 1990; 35: 235-8

132. Allport VC, Slater DM, Newton R, Bennett PR. NF-kappaB and AP-1 are required for cyclo-oxygenase 2 gene expression in amnion epithelial cell line (WISH). Mol Hum Reprod 2000; 6: $561-5$.

133. Subbaramaiah K, Altorki N, Chung WJ, Mestre JR, Sampat A, Dannenberg AJ. Inhibition of cyclooxygenase-2 gene expression by p53. J Biol Chem 1999; 274: 10911-5.

134. Wink DA, Kasprzak KS, Maragos CM, Elespuru RK, Misra M, Dunams TM, et al. DNA deaminating ability and genotoxicity of nitric oxide and its progenitors. Science 1991; 254: 1001-3.

135. Nguyen T, Brunson D, Crespi CL, Penman BW, Wishnok JS, Tannenbaum SR. DNA damage and mutation in human cells exposed to nitric oxide in vitro. Proc Natl Acad Sci U S A 1992; 89: 3030-4.

136. Bartsch H, Ohshima H, Pignatelli B, Calmels S. Endogenously formed N-nitroso compounds and nitrosating agents in human cancer etiology. Pharmacogenetics 1992; 2: 272-7.

137. Plummer SM, Hall M, Faux SP. Oxidation and genotoxicity of fecapentaene-12 are potentiated by prostaglandin $\mathrm{H}$ synthase. Carcinogenesis 1995; 16: 1023-8.

138. Boolbol SK, Dannenberg AJ, Chadburn A, Martucci C, Guo XJ, Ramonetti JT, et al. Cyclooxygenase-2 overexpression and tumor formation are blocked by sulindac in a murine model of familial adenomatous polyposis. Cancer Res 1996; 56: 2556-60.

139. Tsujii M, DuBois RN. Alterations in cellular adhesion and apoptosis in epithelial cells overexpressing prostaglandin endoperoxide synthase 2. Cell 1995; 83: 493-501.

140. Khulusi S, Mendall MA, Patel P, Levy J, Badve S, Northfield TC. Helicobacter pylori infection density and gastric inflammation in duodenal ulcer and non-ulcer subjects. Gut 1995; 37: 319-24.

141. Genta RM, Graham DY. Comparison of biopsy sites for the histopathologic diagnosis of Helicobacter pylori: a topographic study of $\mathrm{H}$. pylori density and distribution. Gastrointest Endosc 1994; 40: 342-5. 